\title{
Critical Dimensions of Mexico-US Migration under the Aegis of Neoliberalism and NAFTA
}

\author{
Raúl Delgado-Wise
}

\begin{abstract}
The main objective of this article is to offer a critical overview of the present nature of Mexico-US migration, taking into account the broad and intricate spectrum of labour relations that has arisen among both nations in the context of the new forms of domination characterizing us imperialism. The article's primary interest lies in penetrating the content and scope of this phenomenon in an attempt to reveal the strategic role played by the exportation of Mexican labour in the process of us industrial restructuring, both within and beyond its borders. For this purpose, five critical dimensions of the phenomenon are analysed: (1) the true face of the economic integration process between Mexico and the United States under the aegis of neoliberalism; (2) the new dynamics of Mexico-Us migration; (3) the particular dialectic between Mexico's export-led growth model and the migration process; (4) the economic and geopolitical implications of the bilateral agenda on migration issues; and (5) the responses and alternative approaches that have emerged from the rank and file of the migrant community itself.
\end{abstract}

RÉSUMÉ - Le principal objectif de l'article est d'offrir un aperçu critique de la nature actuelle de la migration entre le Mexique et les États-Unis en tenant compte du vaste et complexe réseau des relations de travail que ces deux pays ont forgé en raison des nouvelles formes de domination propres à l'impérialisme américain. Le premier intérêt de l'article vient du fait qu'il perce le contenu et la portée du phénomène pour tenter de révéler le rôle stratégique que joue l'exportation de la main-d'œuvre mexicaine dans la restructuration industrielle des États-Unis, tant à l'intérieur qu'à l'extérieur de ses frontières. À cette fin, l'article analyse cinq dimensions essentielles du phénomène : (1) le vrai visage du processus d'intégration économique du Mexique et des États-Unis dans le contexte du néolibéralisme; (2) la nouvelle dynamique de la migration entre le Mexique et les États-Unis; (3) la dialectique particulière du modèle mexicain de croissance axée sur les exportations et du processus de migration; (4) les incidences économiques et géopolitiques du programme bilatéral sur les questions de migration; et (5) les réactions et les nouvelles approches issues de la communauté migrante elle-même.

\section{INTRODUCTION}

As a result of the implementation of neoliberal policies in Mexico, the process of its economic integration with the United States has undergone compelling changes. Not only has trade between the two countries increased but far-reaching transformations associated with the restructuring of binational labour processes have also occurred in the productive arena, and these have had major repercussions on the working realm. All this has taken place within the framework of a new strategy of imperialist domination led by financial capital and large us-headquartered multinational corporations. 
The central aim of this paper is to advance in the analysis of this problematique, focusing on several strategic dimensions of Mexico-Us migration in light of the complex integration process pursued by the two nations. The main hypothesis of the argument offered herein postulates that behind the integration process and current migratory dynamic that exists between Mexico and the United States, there lies a greater subordination of Mexico to the strategic, economic, and geopolitical interests of its northern neighbour, wherein Mexican workers - including those who work inside the country as well as those who emigrate and are employed beyond its borders - are compelled to play a tactical role in the United States' process of industrial restructuring.

For the purpose of this analysis, the paper has been divided into five sections. The first section attempts to reveal the true face of the Mexican export-led model within the process of us-Mexican integration taking place under the neoliberal aegis. Revealing data are then offered about the new migratory dynamic taking place in that context, which has been further accentuated since the signing of the North American Free Trade Agreement (NAFTA). The third section addresses the particular dialectic that exists between Mexico's export-led growth and international migration. The fourth section analyses the content and scope of the bilateral agenda vis-à-vis migration issues as an expression of the new strategy for domination being promoted by us imperialism. The final section briefly describes the responses and alternative approaches that have emerged from the rank and file of the migrant community itself.

\section{The Mexican Export-led Model and the Dynamics of The Integration Process}

Since the late 1970s, the United States has been compulsively pursuing — as a part of a strategy that John Saxe-Fernández $(2001,171)$ has called "neo-Monroeist" — a series of neoliberal-inspired readjustment and restructuring measures in Latin America known as the "Washington Consensus." These measures, put in place by the ruling classes of each country in conjunction with the different international agencies that operate at the service of us imperialism (Guillén 1997; Valenzuela 1996; Veltmeyer 2000), have led to the reorientation of those economies toward exporting, which is in turn associated with different forms of integration.

In this context, the Mexican model is now the most encumbered by its supposedly successful application of the economic reforms - in terms of both their "rhythm" and their "sequence" making Mexico Latin America's leading exporter (with twice Brazil's export volume). Mexico is also, according to the ECLAC'S CAN program that measures competitiveness, the country that produces the goods with the highest technical content in the region. Thus, Mexico has managed to position itself as not only the leading export power in Latin America but also the eighth largest in the world, with an export platform comprising 90\% manufactured goods, of which $39.4 \%$ are classified as goods that "disseminate technological progress" (Katz and Cimoli 2002). Because of the illusion that this positioning could generate, it is crucial to clarify exactly what the country exports and exactly who is involved in this export "boom" and who benefits from it.

The first noteworthy element that emerges from an examination of Mexico's exports is the elevated dynamism and specific weight of maquiladora companies: assembly plants associated with internationalized productive processes that are not highly integrated with the national economy. Between 1982 and 2003, the maquiladora industry's sales abroad increased twenty-fivefold, ultimately accounting for almost half of all manufactured exports (48.5\%). Moreover, that proportion rises to $54 \%$ if the export surplus alone - that is, the difference between the value of the exports and the import requirements - is taken into account (Cypher 2001a, 152). In addition, spectacular 
growth took place in non-maquila manufacturing, exports from which rose twentyfold over the same period. Even more significantly, in some of its more dynamic segments such as the automobile industry, trends toward maquila patterns can be seen based on segmentation and industrial delocalization processes with an exceedingly high import component. ${ }^{1}$ Moreover, reinforcing this trend, the participation of temporal imports in total exports rose to nearly $80 \%$ between 1993 and 2001 (Dussel 2003a, 332).

Another important piece of this peculiar structure is the overwhelming presence, estimated at between $65 \%$ and 75\%, of intra-firm trade within us corporations (Baker 1995, 402; OECD 2002, 165). In addition to contravening the "free market dynamics" preached by neoliberal orthodoxy, this underscores the exceptional plundering of the Mexican economy that is taking place. The concept of shared production inherent in intra-firm trade does not, of course, mean shared profits. Export prices in commerce of this kind are set artificially by the companies without declaring "profits," which not only allows a net transfer of earnings abroad but also enables each job created to be subsidized and the bill for those subsidies to be passed on to the Mexican economy.

Paradoxically, in spite of the Mexican economy's dedication to exports - the total volume of which rose from US\$ 22 million to US\$ 158 billion between 1982 and 2001 — this does not help mitigate the country's severe external deficit problems; on the contrary, it translates into an ever-increasing volume of imports. It is particularly revealing that between 1988 and 1994, manufactured exports grew at an average annual rate (5\%) that was less than half the rate of growth recorded for imports of those same products $(12 \%)$ (Rueda 1998, 110). So pronounced are these tendencies that Enrique Dussel $(1996,80)$ has called this "import-oriented" model industrialization. ${ }^{2}$ And although this import dynamic was momentarily interrupted by Mexico's 1995 economic crisis, it soon picked up again with deficits of slightly over Us\$ 6 billion in 1997 and us\$ 17.5 billion in 2002 .

All of this casts a diminished and relativized view on the scope of the new export dynamic, making it clear that this process, contrary to what might be expected from its evolution toward a model of secondary exporting (i.e., a specialization in manufactured exports), bears little relation to the domestic economy and has a minimal multiplying effect on it.

In addition to showcasing the fragility and volatility of the export dynamic, the comments made above require that we accurately assess the nature and scope of what the country actually exports. In this regard, it is clear that the name "manufactured exports" is too grand a title for most of Mexico's foreign trade, which takes place within the realm of intra-firm commerce and primarily involves the maquiladora sector. As Tello $(1996,50)$ has correctly pointed out, what Mexico essentially exports is its labour force, without ever having it leave the country. Thus, the veil of supposed progress in secondary exports conceals the contraction of a part of the Mexican economy, which is reduced and compelled to serve as a reserve of manpower for foreign capital.

Perhaps it is not superfluous to point out that this export specialization bears some relation to Mexico's direct exports of labour to the United States through labour migration, which indelibly

1. Imported components generally account for between $85 \%$ and $95 \%$ of vehicles exported to the United States (Unger 1990, 77). Fujii $(2000,1014)$ highlights this phenomenon in the following terms: "The dynamism of the export sector does not pull the rest of the economy along with it; instead, it escapes abroad, chiefly to the usa. Two very dynamic export sectors provide good examples of this: automobiles and electronics. Both are dominated by multinational companies, which carry out final assembly of their products in the country, using mostly imported components, and so the industrial sector is beginning to resemble the assembly industries along the border with the usA." Supporting this same line of analysis, Cypher (2001b, 12), holds that: "Mexico's export 'miracle' can be largely explained by globalization strategies drawn up in Detroit the us aute industry accounted for approximately one out of every five dollars of Mexico's non-oil exports during 1997."

2. This tendency is associated with another paradox of the export-led growth neoliberal strategy: the increasing overvaluation of the Mexican currency, estimated in the range of 40\% in 2001 (Dussel 2003b 149). 
marks the nature of commercial exchanges between the two nations. Both cases mean net transfers abroad of potential earnings. Maquiladora plants mean net transfers abroad of profit, while migration deprives the Mexican economy of the main good whereby capital is accumulated.

This analysis of the nature of the Mexican economy's reincorporation into the sphere of us capitalism leads to at least two conclusions. First, labour is the country's chief export good, with a net contribution to the balance of trade in excess of us $\$ 31.6$ billion in 2003 . This estimate includes both the added value of the maquiladora industry, intended as an approximate indicator of indirect labour exports, and the remittances sent home by directly exported workers. Mexico also exports natural resources (primarily oil) and assets. This latter area - the acquisition of the assets of privatized public companies at knock-down prices - is where most direct foreign investment has been channelled, helping concentrate and centralize the capital of large multinational companies. It is worth adding that these investments have been channelled into acquiring the country's financial sector through the purchase of Mexico's largest banks: Bancomer, bought by Banco Bilbao Vizcaya, and Banamex, bought by Citibank.

Second - and perhaps the best illustration of the extremely restricted nature of the process of capital accumulation in Mexico - is the transfer (or, perhaps more correctly, the plundering) of surpluses that takes place in the neoliberal context under the aegis of Us imperialism. The total amount of surpluses transferred from Mexico chiefly to the United States between 1982 (when the shift toward neoliberalism began) and 1997 has been estimated at us\$ 457 trillion, expressed in constant 1990 prices (Saxe-Fernández and Núñez 2001, 150-1). ${ }^{3}$ This calculation includes two types of transfers: those intended as debt service, and those that can be considered trade losses (either through the trade balance or rent, or to pay for franchises, concessions, or patent rights). The true dimensions of this figure, which does not include transfers of potential profits through indirect exports of labour, become apparent if we consider that Latin America is the underdeveloped world's leading tributary region and that, within that region, Mexico is the leading country.

\section{The Escalation of the Migration Phenomenon}

Even though worker migration from Mexico to the United States is a phenomenon with a long history, at present it is showing unprecedented dynamism that has increased since the enactment of NAFTA. For instance, the net annual international migratory flow over the past decade was 10 times higher than the one recorded 20 years earlier (Tuirán, Fuentes, and Ramos 2001, 6). This dynamic also implies major qualitative transformations in terms of the geography of migration (diversification of points of origin and destinations, and greater numbers coming from urban areas), the occupational spectrum of cross-border workers (new fields for insertion into the us job market), migratory patterns (age, sex, schooling, place in the family, duration of stay, legal status, etc.), and the amounts of remittances, the mechanisms used to send and receive them, the uses to which those funds are put, and the impact they have.

To give an idea of the dimensions the phenomenon has acquired, the following figures are more than eloquent.

1. The United States receives the highest levels of immigrant arrivals in the world.

3. To give an idea of the importance of this figure, consider that the total amount of Mexico's GDP in 1997 was Us $\$ 382.6$ trillion at constant prices of 1990 . 
2. Of all Us citizens born abroad, those of Mexican origin constitute the majority (27\%) (CONAPO 2003).

3. The population of Mexican origin living in the United States amounts to 25.5 million, consisting of legal and illegal immigrants born in Mexico (9.5 million) and North Americans of Mexican descent (CONAPO 2003).

4. The flow of temporary migrants ("sojourners") accounts for between 800,000 and 1 million journeys per year (Tuirán 2000).

5. Between 2000 and 2002, an annual average of 390,000 Mexicans established their residence in the United States (CONAPO 2003). This figure corresponds to the world's largest emigration movement.

6. According to the latest estimates by the World Bank $(2003,159)$, Mexico practically equates India as the world's largest receptor of remittances, with a staggering total amount of nearly Us $\$ 10$ billion in 2002 .

7. The Mexico-Us border, which extends for little more than $3000 \mathrm{~km}$ kilometres, is the most crossed border on the planet, with approximately 1 million crossings daily.

Similarly, data from the us Census Bureau (2000) reveal that important qualitative changes have recently taken place within the phenomenon.

1. Although the intensity of international migration varies on a geographical basis, $96.2 \%$ of the country's municipalities report some form of a link with migratory phenomena. Something similar occurs inside the United States, where residents of Mexican origin, while they are mostly concentrated in a handful of states, can be found in practically all parts of the country, including Alaska and Hawaii, where slightly over 100,000 Mexicans live. ${ }^{4}$

2. Of all Mexico-born residents of the United States aged 15 years and older, 55\% completed their secondary schooling or some higher level of education. This figure drops to $40.7 \%$ among the core group of temporary or circular migrants and rises to $71.8 \%$ if the full spectrum of the population of Mexican origin in the United States is taken into consideration. The corresponding national average is $51.8 \%$; in general terms and contrary to common belief, this means that more qualified workers are migrating than remaining in the country.

3. Another form of migration that does not fall in with the traditional stereotypes involves Mexican residents in the United States who have university degrees or post-graduate qualifications. The numbers in question stand at around slightly more than 250,000 people.

4. The employment rate among the economically active Mexican population in the United States is 15 percentage points higher than the corresponding level in Mexico.

5. The number of Mexico-born migrant workers with formal jobs north of the border stands at around 5 million - a figure equal to one-quarter of the workers employed in the formal sector in Mexico.

6. $36.2 \%$ of migrants are employed in the secondary sector (i.e., industry), while the corresponding figure in Mexico is only 27.8\%. This situation contrasts with the stereotypical view of migrants as agricultural workers (in reality, only $13.3 \%$ of Mexican migrants work in the primary sector) and points to a fundamental change in the cross-border labour market.

Along with these characteristics, there has also been a significant increase in the flow of remittances sent to Mexico, which increased fivefold over the past decade to reach a historical maximum of

4. For a more detailed view of the geography of Mexican migration, see Durand and Massey (2003, 97-146). 
Us\$ 13,266 million in 2003 (see Table 1). Not only does that consolidate Mexico's position as the world's main recipient of remittances or "migra-dollars" alongside India, but it also means that exports of labour are the country's third most important source of foreign earnings, with a contribution to the balance of payments that exceeds those made by tourism and agricultural exports.

Table 1. Importance of Remittances in Foreign Exchange Earnings (US\$ million)

\begin{tabular}{lccccc}
\hline Year & Remittances & Tourism & $\begin{array}{c}\text { Sector of Origin } \\
\text { Oil }\end{array}$ & Manufacture & Agriculture \\
\hline 1991 & 2660 & 4340 & 8166 & 32,307 & 2373 \\
1992 & 3070 & 4471 & 8307 & 36,169 & 2112 \\
1993 & 3333 & 4564 & 7418 & 42,500 & 2504 \\
1994 & 3475 & 4855 & 7445 & 51,075 & 2678 \\
1995 & 3673 & 4688 & 8423 & 67,383 & 4016 \\
1996 & 4224 & 5287 & 11,654 & 81,014 & 3592 \\
1997 & 4865 & 5748 & 11,323 & 95,565 & 3828 \\
1998 & 5627 & 6038 & 7134 & 106,550 & 3796 \\
1999 & 5910 & 5869 & 9928 & 122,819 & 4144 \\
2000 & 6572 & 5953 & 16,383 & 145,261 & 4263 \\
2001 & 8895 & 6538 & 12,799 & 141,346 & 4007 \\
2002 & 9814 & 6695 & 14,476 & 142,031 & 3866 \\
2003 & 13,266 & 7252 & 18,654 & 143,031 & 4665 \\
\hline
\end{tabular}

Source: Banco de México

The vital importance of these remittances in offsetting external imbalances becomes even clearer if each sector's net contribution to foreign exchange earnings is analysed. In this case, remittances constitute the second largest source of net income after oil. Moreover, following the fall in international oil prices in 1998, 2001, and 2002, income from remittances managed to secure the top position in those specific years.

Table 2. Contribution of Remittances to the Net External Trade Balance (US\$ million)

\begin{tabular}{lccccc}
\hline Year & Agriculture & Oil and Gas & $\begin{array}{c}\text { Sector of Origin } \\
\text { Manufacture }\end{array}$ & Tourism & Remittances \\
\hline 1991 & 242 & 7030 & $-14,660$ & 1905 & 2660 \\
1992 & -746 & 6896 & $-22,066$ & 1788 & 3070 \\
1993 & -129 & 6054 & $-19,068$ & 1948 & 3333 \\
1994 & -693 & 6265 & $-23,350$ & 2305 & 3475 \\
1995 & 1373 & 7507 & -117 & 3028 & 3673 \\
1996 & -1079 & 10,469 & -124 & 3327 & 4224 \\
1997 & -345 & 9227 & -6023 & 3710 & 4865 \\
1998 & -976 & 5406 & -9881 & 3760 & 5627 \\
1999 & -554 & 8954 & $-10,363$ & 3768 & 5910 \\
2000 & -582 & 11,337 & $-18,638$ & 3990 & 6572 \\
2001 & -1229 & 7764 & $-17,293$ & 3771 & 8895 \\
2002 & -1509 & 8153 & $-13,845$ & 3947 & 9814 \\
2003 & -1067 & 14,406 & $-14,406$ & 4416 & 13,266 \\
\hline
\end{tabular}


The fact that migrant remittances have managed to achieve this status of becoming the source of foreign exchange with the most consistent levels of growth throughout the 1990s not only makes them more visible and attractive to international financial capital, it also places the apologists of the Mexican exporting "miracle" in a decidedly difficult position. Faced with such overwhelming evidence, how can they continue to conceal the underdeveloped nature of Mexico's economy or the profoundly asymmetrical character of the trading relations with us capitalism that it has established?

Moving on to the social arena, the strategic importance of migration is not only reaffirmed, it is redimensioned; as Rodolfo Corona so rightly points out, "the migration phenomenon and its remittances are generalized aspects in the country's life, in that they involve one out of every five Mexican households" (Corona 2001, 38). This situation is even more notorious in the rural areas of nine states in the centre and west of the country, where that figure rises to one of every two households.

\section{Dialectic between Export-led Growth AND INTERNATIONAL Migration}

Another dimension for debunking the myth of the Mexican export "miracle" is the peculiar dialectic that is interwoven between what is euphemistically called the successful sector and the rest of the economy. This dialectic questions two classical concepts that attempt to explain the underdeveloped insertion of economies in classical Latin American economic development theory. The functionalist concept of "structural dualism" (Germani 1974) does not apply, and neither does the concept of "enclave" (Cardoso and Faletto 1974), which has been dusted off to explain the economic integration of Mexico and the United States (Calva 1997, 71-101). In contrast to what those concepts assume, there is no divorce between the successful sector and the rest of the economy, nor can the two be analysed in isolation. On the contrary, the relative increases in the export sector are based on the impoverishment of the remaining sectors.

The export orientation of the Mexican economy demands certain macroeconomic conditions that are obtained by squeezing internal accumulation: in particular, reduced public investment expenditure, the state's withdrawal from strictly productive activities, privatizations, budget deficit controls, and interest rates that are attractive to foreign capital but that, in contrast, depress domestic activity within the economy. This further heightens social inequalities and generates an ever-growing mass of workers who cannot find a place within the country's formal labour market; as a result, a third of the economically active population work in what is called the "informal sector." This is the breeding ground that fuels the vigorous process of cross-border migration that currently exists.

The contradictory dynamic that arises between migration and economic growth in that context can be summarized as follows.

First, international migration brings some "positive" elements for the Mexican economy. On the one hand is the importance of migrants' remittances as a source of foreign exchange for the country. This assumes a new relevance following reductions in other sources of external funding (debt and direct foreign investment) and the drop-off in maquiladora industry exports. ${ }^{5}$ At the same time, with regard to the domestic economy, pressure on the job market is reduced and the risk of social conflict

5. The recession in the us economy and the recent emergence of China as a primary investment option (not only as an export platform, but also as a market in its own right) for us capital began to undermine the Mexican export economy. In particular, it had a devastating effect on maquiladora employment in Mexico (which has fallen systematically since 2001, according to INEGI figures) and, no doubt, will have a similar impact in the semi-maquila sector (where we also include the autopart and automobile industries), leaving the apologists of the North American integration model in an uncomfortable position. 
is diminished, thus enabling migration to act as a kind of escape valve (and a safety valve) vis-à-vis the economy's reduced structural capacity to expand employment. Thus, remittances (family and collective alike but more particularly the latter) help cover social spending and pay for the minimal infrastructure previously supplied through public investment or, alternatively, help cover the subsistence expenses of numerous Mexican households (García Zamora 2003). Consequently, they tend to mitigate the distributive conflict between the state and the most vulnerable groups in the social spectrum, improving to some extent the levels of poverty and marginalization that prevail in the areas where migration is most common.

Second, over and above the previous remarks, migration in and of itself implies that the economy loses valuable resources through these exports of potential wealth. In turn, exporting labour implies transferring to the receiving country the costs of reproducing and training those resources that were originally covered by the Mexican population as a whole.

Third, unlike labour that is exported indirectly (through maquiladoras), workers who emigrate and settle in the United States consume a very significant part of the wages in that country, whereby the potential multiplying impact of their earnings is transferred to the us economy. Note that, in 2000, the incomes of workers of Mexican origin in the United States totalled some Us $\$ 250$ billion, of which us $\$ 87$ billion were earned by Mexican-born emigrants. These amounts contrast sharply with the remittances sent back to Mexico, which, impressive as they may seem, accounted for a total of Us\$ 6.57 billion during that same year.

Fourth, from a fiscal point of view, international migrants contribute more to the receiving economy than they receive in benefits and public services. Through transfers of resources, migrants contribute to the mass of social capital available to the Us state. According to data from The National Immigration Forum (Moore 1998), during 1997 the migrant population in the United States contributed US $\$ 80$ billion more to that country's coffers than they received in benefits from the us government at the local, state, and national levels. With these contributions, migrants dynamize the receiving economy.

Fifth, although this aspect is difficult to quantify, by bringing pressure to bear on the job market, migrants tend to have an adverse affect on wage increases in the receiving economy, particularly in the areas and sectors in which they are employed. In connection with this, a recent study by Papail (2001) points out that the gap between the average income of migrant workers and the Us federal minimum wage has been decreasing for the past 25 years. Measured in constant 2000 prices, the minimum wage fell by $38 \%$ over that period, from us $\$ 11.70$ to us $\$ 7.20$ per hour. The paradox of this situation is that it is taking place alongside the changes in migrant profiles described above - in other words, that migrants now have higher education standards and greater presence in the manufacturing sector.

This clearly reveals the perverse dialectic that arises between the Mexican export dynamic and international migration. While it falls to Mexico to reproduce and train the workers it exports (both directly and indirectly), the United States avails itself of those advantages to restructure its industry and reduce its costs.

\section{The Vicissitudes of the Binational Agenda}

Neither Mexico nor the United States recognize an international migration agenda commensurate with a reality that exists. They consequently fail to act in accordance with this agenda. However, given its importance to the two countries, it is impossible to ignore.

Using strict cost-benefit calculations (with the clear aim of avoiding a confrontation with the 
United States, particularly with regards to undocumented migrants), from 1974 until very recently the Mexican government chose to follow a peculiar strategy that García y Griego (1988) calls "the policy of no policy," entailing the absence of any explicit policy on migration matters.

The negotiation and enactment of NAFTA served as a fundamental point of reference for the subsequent course of bilateral relations and, in particular, of international migration. The Mexican government's agreement to exclude the issue of migration from the negotiation agenda and adhere acritically to the principle of free movement for investments and goods reaffirms not only its lack of commitment toward the migrant sector but also its frank and, in this instance, open subordination to the hegemonic interests of the United States.

The same attitude can be seen in the Mexican government's lukewarm stance vis-à-vis Washington's ferocious assault on the human and labour rights of Mexican migrants. Among the many measures introduced by the United States to install a regime of terror along the border with Mexico are the countless operations deployed by its Immigration and Naturalization Service (INS) to curtail, at any cost, the growing flow of labour migrants. Bearing in mind that Mexico ranks as the United States' number two trading partner, this is far from a civilized "good neighbour" policy between partners. One clear indicator of the vehemence with which the anti-immigration policy is being pursued is the increasingly generous - some might say exorbitant — budget given to the INs, totalling Us $\$ 4.18$ billion in 1999. In line with the xenophobia behind the failed Proposition 187 of California Governor Pete Wilson, on 30 September 1996 the Illegal Immigration Reform and Immigrant Responsibility Act came into effect. This legislation (which is still in force) was important in that it institutionalized the criminalizaton of labour migration through a series of arbitrary procedural provisions that violate the human and labour rights of cross-border workers (Mohar 2001, 51). One of the most reprehensible outcomes of this "hard-line" approach within us immigration policy has been the proliferation of Mexican deaths along Mexico's northern border, totalling 1236 between 1998 and 2000 (Villaseñor and Morena 2002, 13); recourse is thus being made to "death as an element in dissuading migration," ratifying the predisposition toward state terrorism as an essential ingredient in Us foreign policy and domestic security.

Significantly, the Mexican government's chief response to those challenges was the enactment of legislation under which Mexican nationality could not be lost. This was, essentially, a measure intended to help Mexicans in the United States defend their rights, allowing them to acquire us citizenship without losing Mexican nationality (Martínez 1999, 251). However, one area of constant conflict is the fact that the law still does not grant sufficient guarantees to those who use it and wish to enjoy full exercise of their Mexican citizenship; that is, the right to vote and to run for public office. It should be noted that the law in question, which came into effect on 20 March 1998, has been taken up and reinterpreted by the organized migrant community in the United States, who are demanding, with increasing vehemence, full political rights.

The onset of Vicente Fox's presidency in December 2000 brought on a reassessment of the migration question, placing it for the first time ever in the history of Mexico-Us relations as a priority issue on the bilateral agenda (Castañeda 2001, 69). How should the change in positions on the part of the two governments be interpreted? What reading should be made of the negotiation agenda they agreed on? What interests does it serve? And what are its real implications? Moreover, considering the five main issues on the agenda — straightening out migrants' status, a temporary worker program, increased visa numbers, strengthening borderland security, and promoting development programs in high migration areas - what assessment can we make of the progress made in the negotiations?

Although the bilateral agenda was virtually cancelled after 11 September 2001, there are, at pres- 
ent, new efforts to re-establish negotiations. For this reason it is important to analyse the above issues with some detail so as to reveal the hidden agenda behind the negation process.

First of all, the change in the governments' positions regarding migration is based on their recognition of a reality: the burgeoning growth of the migration phenomenon (contradicting the predictions and preachings of neoliberal doctrine) and the United States' inability to contain it (or, better put, to regulate it) on a unilateral basis using strict police and military measures, such as those provided for in the 1996 Illegal Immigration Act (Mohar 2001, 54). Because of the recession affecting the us economy and its knock-on effect on the Mexican economy, these problems are accentuated and redimensioned from the perspective of the hemispheric security of the world's leading capitalist power.

Even though these five issues on the bilateral agenda address matters of interest to the migrant community, they avoid one issue of key importance to Mexico's strategic interests: the liberalization of migratory flows. The agenda is therefore structurally limited in that it fails to address a key aspect of the root causes of international migration and that, on the contrary, and as the Mexican government itself has stated, it is aimed at "evolving toward a regime of ordered flows" or regulated migration. It is not difficult to see that the negotiating dice are loaded in favour of the United States' strategic interests and that, in the worst case scenario, it will continue to benefit from a reserve of cheap Mexican labour. Consequently, President Fox's comment, made in his first State of the Nation address and reiterated in former Foreign Minister Castañeda's annual report, that "for the first time in history, the United States has agreed to negotiate the migration issue on a comprehensive basis with another country" is inaccurate.

With respect to the "progress" made with each of the items on the binational agenda, the following comments and observations are of relevance. First of all, to date there has practically been nothing of importance to report regarding the migratory status of the three million Mexicans stigmatized as "illegals." The only information available notes that any possibility of an "amnesty" (a term proper to the criminalization of labour migration) has been virtually dismissed by the us government and replaced by a more modest program of "acquired adjustment" (Miller and Seymour 2001, 1). Thus, in February 2002, the INS announced that the so-called "amnesty" could benefit some 300,000 Mexicans.

Second, the question of temporary workers is clearly one that has fuelled keen interest among US authorities and lawmakers alike. Everything points toward the launch of a program that will allow a given number of Mexicans to legally work in the United States for a guaranteed minimum wage and access to some health benefits, provided that they return to Mexico after one year and that the number of workers allowed to register is annually adjusted in response to the conditions prevailing in the Us economy, particularly unemployment rates (Roldán 2001, 85). This program, which has been styled as involving guest workers - perhaps in an attempt to disassociate it from the discredited Bracero Program - clearly demonstrates one of the basic pillars of Washington's position in the negotiating process. With its "generous" offer of extracting millions of Mexican labour migrants from under the "shadow of illegality" and "granting" them minimum labour rights, the program proposes, in the words of its chief advocate, Senator Gramm, "strengthening the us economy and stimulating [through the remittances sent back to Mexico and the skills acquired by the "guest" workers in the program] Mexico's long-delayed economic development." In accordance with this idea, a pilot experiment was carried out in the state of Zacatecas, involving the Us companies LEH Packing Company, ACME Brick, Kanes, San Angelo, and Marcus Drake (García Zamora and Moctezuma 2001). And, although everything indicates that the program has President Fox's blessing, the "United Conference of Mexicans Abroad," an umbrella group representing some 20 political organizations, has stated its 
flat-out "rejection of the guest or temporary worker program" and its disagreement with the fact that the migrant community's representatives were excluded from the negotiations (El Universal 5 Jan. 2002).

Third, no information is available on possible progress in the numbers of visas allotted to Mexicans. The INs' per-country information gives updated figures for 1999 only, as does the Web page of the us embassy in Mexico. The only figure we have is that in the H-2a visa program (temporary farm workers), Mexico's share in comparison to other nationalities fell between 1995 and 2000.

Fourth, of the five issues on the bilateral agenda, the matter of borderland security is by far the one that has received the most attention from both governments, regarding which the greatest common ground has been identified. In this case, as with the guest worker program, the vision and interests of Mexico's northern neighbour have been imposed. A clear example of this can be seen in the Plan of Action for Cooperation on Border Safety, signed on 22 June 2001, which includes: "stopping people up to $3 \mathrm{~km}$ to the south of the border; having the Border Patrol and the Grupos Beta carry out operations to 'dissuade' migration; and exchanges of information between the Office of the Attorney General of the Republic (PGR) and the Naturalization and Immigration Service (INS) to combat smuggling gangs" (Sandoval 2001, 252). This is a set of coordinated operations through which Mexico's police forces are placed at the service of Us security and assigned tasks in combating undocumented migration, under the aegis of a supposed commitment toward protecting the human rights of the citizenry. The 377 Mexican migrants who died during 2001, the $29 \%$ increase in the INs' budget (announced by President Bush on 29 January 2002), and the decision to increase by almost $800 \%$ the number of National Guard members deployed along the border (divulged by the White House on 6 February 2002) are unequivocal signals that human rights do not feature among Washington's priorities.

At the same time, the Mexican authorities' lukewarm reaction to the violence and terrorism unleashed by the us government reveals that human rights are not a priority for the Fox administration, either. Worse still, in exchange for certain concessions vis-à-vis Mexican labour migration which, to date, have been nothing more than empty promises - the Mexican government has agreed to serve as the United States' sentry on its own southern border under the Plan Sur.

This latter program, launched on 1 July 2001, was designed to reduce the porous nature of Mexico's borders with Guatemala and Belize through a heightened police and military presence. This was to be done within the framework of the commitment the Fox administration acquired with Washington to reduce the flow of undocumented immigrants reaching the common border (Sandoval 2001, 252). This is, above all, an operation to seal off Mexico's southern border through police and military controls, which reproduces within the country the security system designed by the United States, and assigns the Mexican government the "dirty work" of curtailing migration from Central and South America in an unprecedented demonstration of servility and subordination. President Fox's recent offer to tighten up controls on flows of migrants explicitly reaffirms that position (La Jornada 14 Feb. 2002).

The fifth area is regional development in the areas of highest migration, where progress has been practically non-existent. So far, there have been no signs of any such initiatives involving the governments of the two countries. All that exist are mechanisms run by state governments such as the $3 \times 1$ program in Zacatecas, "My Community" in Guanajuato, and, most recently, with backing from the Fox administration, "Adopt a Community" (Reforma 20 Jan. 2002). The aim of the first two programs is to channel collective funding from migrants into social projects (Torres, 1998). The peculiar feature of the third program — to be put in place in five Mexican states - is that it has been designed as a strategy for fighting poverty. This approach, however, is based on a mistaken view of the relationship 
between marginalization and international migration. The severe structural restrictions imposed by the neoliberal context notwithstanding (Veltmeyer and O'Malley 2001), none of these programs seriously addresses the possibility of using the potential offered by remittances and other resources available to the migrant community to further local and regional development (Delgado-Wise and Rodríguez 2001).

From what has been said, it is clear that the results of the bilateral negotiations on migration issues have mainly favoured the United States' strategic interests in the arenas of geopolitics (hemispheric security) and geoeconomics (availing itself of the advantages Mexico offers in terms of cheap labour and natural resources). In many ways, this negotiation process resembles a zero-sum game, where what is gained by one side is lost by the other, and in this asymmetrical negotiation process that has nothing to do with the principle of shared responsibility, the dignity that for so long characterized the foreign policy pursued by the Mexican government has ultimately been disfigured and replaced by open subordination.

\title{
V. The Migrant Community and the Challenges of Neoliberal Globalism ${ }^{6}$
}

To conclude my analysis, it is appropriate to note, as Petras does, that:

\begin{abstract}
The idea that some intellectuals have - that there is a need to create an alternative - is, of course, an expression of their ignorance about the alternatives that exist in the creation process and/or their unconscious acceptance of the argument of globalization that holds that there are no alternatives. Instead of repeating timeworn clichés about the "need for alternatives," it would be better to relate now to the alternatives currently being prepared by the opposition movements.

The alternatives are there for them to be given greater substance, coherence, and prominence in the nation-state and even beyond. (Petras 2001, 85)
\end{abstract}

It should therefore be pointed out that today's migrant community appears much less isolated, dispersed, and disorganized than in the past. As a contradictory by-product of the historic evolution and maturing process of migratory social networks, individual migrants have embarked on an increasingly perceptible and significant evolution toward becoming what Miguel Moctezuma (2001) has called binational and transterritorial collective agents. This process is taking shape through the emergence of a wide array of clubs (currently totalling more than 500), associations of clubs, statebased federations in several us states, and multiple alliances and coalitions between organizations from different states with a national and binational outlook. The migrant community progresses toward higher levels of organization, characterized, inter alia, by: (1) having a relatively permanent formal organization; (2) using it to strengthen ties of cultural identity, belonging, and solidarity with their places of origin; (3) opening up the potential for dialogue with different public and private agencies, in both Mexico and the United States; and (4) enjoying a not inconsiderable financial potential — through collective funds that transcend the limitations and constraints inherent in indi-

6. This term is used to distinguish our treatment of globalization — considering it as a new phase of imperialism from the more common, rhetorical discourse that tends to obscure the nature of this phenomenon by presenting it as something inevitable, characterized by John Saxe-Fernández (1999) as "pop globalism" and by James Petras and Henry Veltmeyer (2001) as "globaloney." 
vidual or family remittances - for undertaking public works projects and, ultimately, local and regional development efforts.

One of the demands that has stirred up the most interest among migrant communities is for them to be able to fully exercise their rights as Mexican citizens while abroad. This demand, which is an immediate consequence of the 1998 constitutional amendment whereby Mexican nationality could not be lost, brings together three claims that go against the grain of the ideology and practices of neoliberal globalism: (1) strengthening national identity, the opposite tendency to the disintegration and fragmentation inherent in globalism; (2) collective support for local and regional development, in opposition to the destruction of the domestic market and the country's productive base caused by neoliberal restructuring; and (3) bottom-up democracy, attacking the separation between the political class and civil society that neoliberal "democracy" has exacerbated (Petras and Veltmeyer 2001, cap. 6).

On the other hand, the demands of the migrant community in the United States are directed toward straightening out their legal status, securing full rights as citizens, and creating a multicultural society, in contrast to political exclusion, social marginalization, and the constant formation of ethnic minorities and ghettoes (Castles and Miller 2003). We could also add their demand for open borders, which is directed at one of the key elements in the strategy for imperialist domination that guides relations between Mexico and the United States (Wihtol de Wenden 1999).

\section{REFERENCES}

Baker, G. (1995) “Sector externo y recuperación económica en México,” Comercio Exterior 45:5, 398-408.

Calva, J.L. (1997) “Mercado y Estado en la economía mexicana. Retrospección y prospectiva," Problemas del Desarrollo 109, 71-101.

Cardoso, F.H. and E. Faletto (1974) Dependencia y Desarrollo en América Latina, Mexico: Fondo de Cultura Económica.

Castañeda, J. (2001) “Los ejes de la política exterior de México," Nexos 288, 66-74.

Castles, S. and M.J. Miller (2003) The Age of Migration. International Population Movements in the Modern World ( $3^{\text {rd }}$ ed.), Great Britain: Macmillan Press.

conapo (2003) "Indicadores de la Migración México-Eu," [on-line], [cited 24 April 2004], $<$ http://www.conapo.gob.mx/migracion_int/principal.html $>$.

Corona, R. (2001) “Monto y Uso de las Remesas en México," El Mercado de Valores LXI:8, 27-46.

Cypher, J.M. (2001b) “Developing Disarticulation Within Mexican Economy," Latin American Perspectives 8:3, $11-37$.

—_. (2001a) "El modelo de desarrollo exportador: El caso de México," in G. Vidal (ed.) Mundialización, transnacionalización y subdesarrollo, Mexico: UAM, UNAM, UAZ, 137-62.

Delgado-Wise, R. and H. Rodríguez (2001) “The Emergence of Collective Migrants and Their Role in Mexico's Local and Regional Development," Canadian Journal of Development Studies XXII:3, 747-64.

Durand, J. and D. Massey (2003) Clandestinos. Migración México-Estados Unidos en los albores del siglo XXI, México: Miguel Ángel Porrúa/uaz.

Dussel, E. (2003b) "Características de las empresas generadoras de empleo en la economía mexicana, 1988-2000," Investigación Económica 243, 123-54.

—. (2003a) "Ser maquila o no ser maquila, ¿es ésa la pregunta?, Comercio Exterior 53:4, 328-36.

(1996) "From Export-Oriented to Import-Oriented Industrialization: Changes in Mexico's Manufacturing Sector, 1984-1994," in G. Otero (ed.) Neo-liberalism Revisited: Economic Restructuring and Mexico's Political Future, Boulder: Westview Press, 63-83.

Fujii, G. (2000) "El comercio exterior manufacturero y los límites al crecimiento económico de México," Comercio Exterior 50:11, 954-67. 
García y Griego, M. (1988) "Hacia una nueva visión del problema de los indocumentados en Eu," in M. García y Griego and M. Verea (eds.) México y EU frente a la migración de los indocumentados, Mexico: UNAM and Miguel Ángel Porrúa.

García-Zamora, R. (2003) Migración, Remesas y Desarrollo Local, México: Doctorado en Estudios del Desarrollo/UAZ.

García-Zamora, R. and M. Moctezuma (2001) “Trabajadores Temporales contratados por eU. Informe sobre el programa piloto del Gobierno de Zacatecas," presented in Mesa Redonda Binacional, Programa de Trabajadores Temporales México-eu, Guadalajara, Mexico, 16 May 2001.

Germani, Gino (1974) Industrialization and modernization, in Helen Hemingway Benton (ed.) Encyclopaedia Britannica, usa: Encyclopaedia Britannica, Inc.

Guillén, H. (1997) La contrarrevolución neo-liberal, Mexico: Era.

Katz, Jorge and Mario Cimoli (2002) "Reformas estructurales, brechas tecnológicas y el pensamiento del Dr. Prebisch," presented in Seminario Internacional "El Desarrollo en el Siglo XXI" en conmemoración del centenario de Raúl Prebisch, Santiago de Chile: CEPAL.

Martínez, J. (1999) "Los emigrados y la nación mexicana: la evolución de una relación," in M. Moctezuma and H. Rodríguez (eds.) Impacto de la Migración y las Remesas en Crecimiento Económico Regional, Mexico: Senado de la República, 241-59.

Miller, S. and A. Seymour (2002) "Third Binational Roundtable on México-u.s. Migration: The New Bilateralism," [on-line], Mexico-U.S. Advocates Network News 12, [cited 22 February 2004], $<$ http://www.enlacesamerica.org/news_esp/newsarchivespdf/Mexico_us_Adv_Ntwk_1101.pdf > .

Mohar, G. (2001) “Historia Reciente y Debate en Eu sobre Migración y Presencia de los Mexicanos,” El Mercado de Valores LXI:8, 47-55.

Moctezuma, M. (2001) “Clubes Zacatecanos en los Eu. Un Capital Social en Proceso," presented in Segundo Seminario sobre Migración Internacional, Remesas y Desarrollo Regional, Zacatecas, Mexico, 21-22 September 2001.

Moore, S. (1998) "A Fiscal Portrait of the Newest Americans," The National Immigration forum [on-line], Cato Institute, [cited 17 May 2003], <http://www.immigrationforum.org >.

oCDE (2002) Economic Outlook [on-line], <http://www.oecd.org/dataoecd/6/18/2752923.pdf>.

Oxfam (2002) Rigged Rules and Double Standards. Trade, globalisation, and the fight against poverty, [on-line], [cited 24 April 2004], $<$ http://www.maketradefair.com/assets/english/Report\%20Chapter\%205\%20English.pdf >.

Papail, J. (2001) "Remesas e inversiones de los ex-migrantes internacionales radicados en áreas urbanas de Jalisco, Guanajuato y Zacatecas," presented in Segundo Seminario sobre Migración Internacional, Remesas y Desarrollo Regional, Zacatecas, Mexico, 21-22 September 2001.

Petras, J. (2001) “La globalización: un análisis crítico," in J. Saxe-Fernández and J. Petras (eds.) Globalización, Imperialismo y Clase Social, Buenos Aires: Lumen-Hvmanitas, 33-85.

Petras, J. and H. Veltmeyer (2001) Globalization Unmasked. Imperialism in the 21st Century, Canada: Zed books/Fernwood Publishing Company.

Roldán, G. (2001) “Política migratoria y derechos humanos,” Diversa 2-3, 71-87.

Rueda, Isabel (1998) México: crisis, reestructuración económica, social y política. México: IIE, UNAM-Siglo XXI.

Sandoval, J.M. (2001) "El plan Puebla-Panamá como regulador de la migración laboral mesoamericana," in Armando Bartra (ed.) Mesoamérica. Los Ríos Profundos. Alternativas Plebeyas al Plan Puebla-Panamá, Mexico: Instituto Maya-El Atajo Ediciones-Fomento Cultural y Educativo-RMALC-Equipo Pueblo-CAsifopANEC-CCECAM-SEMAPE CEN-PRI.

Saxe-Fernández, J. (1999) “Globalización e Imperialismo" in J. Saxe-Fernández (ed.) Globalización: Crítica de un Paradigma, México, Plaza y Janes.

—_. (2001) "América Latina-Eu en la posguerra fría" in J. Saxe-Fernández and J. Petras (eds.) Globalización, Imperialismo y Clase Social, Buenos Aires: Lumen-Hvmanitas, 167-208.

Saxe-Fernández, J. and O. Núñez (2001) "Globalización e Imperialismo: la transferencia de excedentes de América Latina" in J. Saxe-Fernández and J. Petras (eds.) Globalización, Imperialismo y Clase Social, Buenos Aires: Lumen-Hvmanitas, 87-165. 
Tello, C. (1996) “La economía mexicana: Hacia el tercer milenio," Nexos 223, 47-55.

Torres, F. (1998) “Uso productivo de las remesas en El Salvador, Guatemala, Honduras y Nicaragua," CEPAL. LC/MEX/R.662.

Tuirán, R. (2000) "Desarrollo, comercio y migración: el caso de México," presented at the Seminario: Los Acuerdos de Libre Comercio y sus Impactos en la Migración, Guatemala, 15-16 November 2000.

Tuirán, R., C. Fuentes, and L.F. Ramos. (2001) “Dinámica Reciente de la Migración México-eu,” El Mercado de Valores LXI:8, 3-26.

Unger, K. (1990) Las exportaciones mexicanas ante la reestructuración industrial internacional: la evidencia de las industrias química y automotriz, Mexico: Colegio de México-FCE.

Valenzuela Feijóo, J. (1996) El Neo-liberalismo en América Latina. Crisis y Alternativas, La Paz: Cides-umsa.

Veltmeyer, H. (2000) El capital global y las perspectivas de un desarrollo alternativo, Mexico: UNESCO-UAZ-COBEAz.

Veltmeyer, H. and A. O’Malley (2001) Transcending Neo-liberalism. Community-Based Development in Latin America, Canada: Kumarian Press.

Villaseñor, B. and J. Morena (2002) "Breve visión sobre las medidas de control migratorio en la frontera norte de México," in Migración: México entre su dos fronteras, Mexico: Foro Migraciones.

Waller Meyers, D. (2000) “Remesas de América latina: revisión de la literatura," Comercio Exterior 50:4, 275-88.

Wihtol de Wenden, C. (1999) Faut-il ouvrir les frontières?, Paris: Presses de Sciences Po, La bibliothèque du citoyen.

World Bank (2003) Global Development Finance. Striving for Stability in Development Finance, Washington: The World Bank. 
